\title{
EHMTI-0097. Long-term outcome in 201 patients with chronic headache with medication overuse
}

\author{
J Zidverc-Trajkovic ${ }^{1 *}$, T Pekmezovic ${ }^{2}$, A Radojicic $^{3}$, A Podgorac $^{4}$, N Sternic ${ }^{3}$ \\ From 4th European Headache and Migraine Trust International Congress: EHMTIC 2014 \\ Copenhagen, Denmark. 18-21 September 2014
}

From the cohort of 240 patients with chronic headache with medication overuse $(\mathrm{MOH})$, treated with drug withdrawal and prophylactic medications and evaluated at 1-year follow-up, $57.1 \%$ were without chronic headache and without medication overuse, $3.3 \%$ did not improve after drug withdrawal and $39.6 \%$ relapsed developing recurrent overuse (Cephalalgia 2007; 27:1219-25).

The aim of the present study was to evaluate the longterm outcome of these patients.

During the next 1-12 years, follow-up examinations were performed in 201 (83.8\%) patients. There were no significant differences between patients lost for further examination and other patients regarding age and gender, as well as the outcome on 1-year follow-up.

On the last follow-up, 66 (32.8\%) patients had chronic headache with medication overuse. Without overuse were 130 (64.7\%) patients with episodic and five (2.5\%) patients with chronic headaches. During the follow-up period, 47 (23.4\%) patients had relapsed developing recurrent overuse. The recurrent overuses occurred once in 33 (16.4\%), twice in $13(5.0 \%)$ and thrice in four (2.0\%) patients. $\mathrm{MOH}$ recurrence occurred during the first three years after the first-year follow-up in three quarters of patients. The majority of patients, $33(70.2 \%)$, overused the same medication. Treatment of $\mathrm{MOH}$ recurrence was efficacious in $93.6 \%$ patients, with strong advice to cease overused drug in $79.0 \%$ and prophylactics in $83.0 \%$ patients. During the examined period 20 (23.3\%) of the patients with $\mathrm{MOH}$ on the first-year follow-up had remission of chronic headache with subsequent decrease of medication use.

No conflict of interest.

\section{Authors' details}

'Headache Center, Neurology Clinic, Belgrade, Serbia. ${ }^{2}$ Institute of Epidemiology, Faculty of Medicine University of Belgrade, Belgrade, Serbia. ${ }^{3}$ Headache Centar, Neurology Clinic, Belgrade, Serbia. ${ }^{4}$ Neurology, Faculty of Medicine University of Belgrade, Belgrade, Serbia.

Published: 18 September 2014

doi:10.1186/1129-2377-15-S1-D78

Cite this article as: Zidverc-Trajkovic et al.: EHMTI-0097. Long-term outcome in 201 patients with chronic headache with medication overuse. The Journal of Headache andPain 2014 15(Suppl 1):D78.
Submit your manuscript to a SpringerOpen ${ }^{\circ}$ journal and benefit from:

- Convenient online submission

- Rigorous peer review

- Immediate publication on acceptance

- Open access: articles freely available online

- High visibility within the field

- Retaining the copyright to your article

Submit your next manuscript at $\boldsymbol{~ s p r i n g e r o p e n . c o m ~}$

\section{SpringerOpen ${ }^{\circ}$}

@ 2014 Zidverc-Trajkovic et al; licensee Springer. This is an Open Access article distributed under the terms of the Creative Commons Attribution License (http://creativecommons.org/licenses/by/2.0), which permits unrestricted use, distribution, and reproduction in any medium, provided the original work is properly cited. 